\title{
Social nature: theory, practice and politics
}

Link to publication record in Manchester Research Explorer

\section{Citation for published version (APA):}

Castree, N., \& Braun, B. (Ed.) (2001). Social nature: theory, practice and politics. Basil Blackwell Ltd.

\section{Citing this paper}

Please note that where the full-text provided on Manchester Research Explorer is the Author Accepted Manuscript or Proof version this may differ from the final Published version. If citing, it is advised that you check and use the publisher's definitive version.

\section{General rights}

Copyright and moral rights for the publications made accessible in the Research Explorer are retained by the authors and/or other copyright owners and it is a condition of accessing publications that users recognise and abide by the legal requirements associated with these rights.

\section{Takedown policy}

If you believe that this document breaches copyright please refer to the University of Manchester's Takedown Procedures [http://man.ac.uk/04Y6Bo] or contact uml.scholarlycommunications@manchester.ac.uk providing relevant details, so we can investigate your claim.

\section{OPEN ACCESS}




\title{
Chapter 1
}

\section{Socializing Nature: Theory, Practice, and Politics}

\author{
Noel Castree
}

For over a century, geographers have sought to describe and explain the society-nature interface. When, James Bryce (1886, p. 426) - one of geography's early advocates - characterized the discipline as "a meeting point between the sciences of Nature and the sciences of Man [sic]" he sought to create a distinctive place for it within the academic division of labor. As we enter the twenty-first century, geography remains one of the few subjects dedicated to exploring the relations between humanity and nature. To be sure, the geographical project extends beyond the study of these relations. But many geographers remain convinced that the society-nature nexus should be a central disciplinary preoccupation. It's easy to understand why. The world has changed enormously since Bryce penned his words in the genteel surroundings of Victorian Oxford, where he was a university professor. In the twenty-first century, society-nature relations seem to be marked by a new breadth, depth, and consequentiality. By breadth, I simply mean that few areas and aspects of nature today remain untouched by human hands; by depth, I mean that many society-nature relations extend 'all the way down,' even to the level of genetic modification; and by consequentiality, I mean that what happens to nature today may be of world-changing importance, both for ourselves and other species. In short, Bryce could scarcely have anticipated a future in which mass deforestation, global warming, the collapse of commercial fisheries, chronic species extinction, transgenic organisms, a growing ozone 'hole,' and desertification would be just a few of the problems arising from human transformations of nature. And he could hardly have imagined that such problems would spawn a global environmental movement, or that governments worldwide would put the question of nature near the top of their political agendas.

So where does contemporary geography figure in this maelstrom of socionatural change? Like most other academics, geographers respond to forces external to their discipline, in terms of what they study, how they study it, and 
the use to which the resulting knowledge is put. Arguably, there are three broad approaches to the society-nature problematic that are current in the discipline, one mainstream, two more radical. This book is the first devoted to presenting and evaluating the third, and most recent, of these approaches: namely the 'social' approach. This new perspective, as I hope to show in the pages that follow, is both innovative and exciting. In reality, it's less a unified worldview than a plurality of related positions and arguments. Before outlining these arguments, though, we need to relate the social view of nature to the other two approaches to society-nature relations current in geography: for it poses a provocative challenge to both of them.

\section{The 'Nature' of Contemporary Geography: Three Approaches}

The first, and arguably dominant, approach is a revivified 'people and environment' perspective. For many geographers, the early twenty-first century represents a timely opportunity to 'reclaim the high ground': that is, to refocus disciplinary research and teaching on the 'big' questions of our era concerning the problems and possibilities resulting from the human alteration of natural resources, environments, and organisms. I say refocus, because for commentators like David Stoddart (1986) geography has in recent decades become a divided discipline, with human and physical geographers drifting further apart as they pursue their own specialist interests. This is why he and others (e.g. Cooke, 1992), echoing Bryce's original prospectus for geography, argue for greater disciplinary coherence founded on the study of contemporary societyenvironment relations.

This injunction to 'unify' a currently schizoid geography is, at first sight, appealing. It promises to renew the discipline's distinctiveness as a 'bridge' between the social sciences, humanities, and natural sciences. As importantly, it also promises to make geography intensely relevant to some of the most pressing and profound issues of our age. Consequently, we are now seeing many geography departments refocus their research and teaching so as to ride the wave of contemporary concern about nature. For example, the University of Oxford - where Halford Mackinder, supported by Bryce, established one of Britain's first geography degrees in the 1880s - now has a high-profile Environmental Change Unit affiliated to the School of Geography. Meanwhile, across the Atlantic, the USA has in recent years instituted a major Global Change Program which, under the auspices of the National Oceanic and Atmospheric Administration, funds environmental research by geographers and fellow-travelers. ${ }^{1}$

However, while many geographers agree that this is a vital time for the discipline to anatomize the society-nature problematic, not all them concur with the Stoddartian vision of how such anatomization should proceed. This 
brings us to the two other approaches to society-nature now advocated in geography: the 'ecocentric' and 'social' approaches. Both are relatively new to the discipline, and both are associated with so-called 'critical geographers.' I'll explain the differences between them momentarily, but first it's useful to explain what they have in common. For critical geographers of an ecocentric and social persuasion, Stoddart's brand of 'human-environment relations' geography - far from being objective and neutral - is intellectually limited and politically biased. It's intellectually limited, the argument goes, because it equates nature with 'environmental problems', so ignoring other important human-environment relations (like commercial agriculture or forestry) and non-environmental natures (like the human body). And it's politically biased, so several critical geographers claim, because the knowledge it produces tends to be 'technocratic.' Articulated in the subdisciplines of 'resource-' and 'environmental management' and claiming the mantle of 'science,' what makes this knowledge technocratic is that it rarely discusses the fundamental socioeconomic processes transforming twenty-first century nature. Instead, it is knowledge that leads to policy geared to ameliorating environmental problems without ever addressing the deeper causes responsible for those problems in the first place. It is, in other words, knowledge by and for those with a vested interest in not having to pay the price for eradicating environmental problems altogether. For several critical geographers, the most prominent example of this kind of knowledge is that articulated in the concept of 'sustainable development,' an appealing but ultimately amorphous idea that can easily serve as a rhetorical cover for business-as-usual (see Redclift, 1996).

In light of this, a fast-growing cohort of human geographers have argued for approaches to the society-nature interface that are broader and deeper than that offered by the 'people and environment' tradition. The 'ecocentric' or nature-first approach urges a fundamental respect for, and need to get back to, nature. This is to be achieved through a profound critique and dismantling of existing systems of production and consumption. This way of thinking has grown out of the now popular 'green movement,' whose influence in many Western and several non-Western nation-states has grown enormously since the early 1970s. It's a way of thinking that can be contrasted with the third approach to society-nature relations currently extant in geography, the one that is the subject of this book. This approach - which is increasingly popular and influential among critical human geographers - sees nature as inescapably social. Here the argument is that nature is defined, delimited, and even physically reconstituted by different societies, often in order to serve specific, and usually dominant, social interests. In other words, the social and the natural are seen to intertwine in ways that make their separation - in either thought or practice - impossible.

Their differences notwithstanding, the ecocentric and social approaches regard the 'people and environment' style of geography as a hindrance to 
adequately understanding and altering society-nature relations. For ecocentrists, the technocratic knowledge it produces is unable to treat nature as anything other than a 'resource' to be used, destroyed, or regulated for mainly human benefit. For advocates of a social approach to understanding the natural, the technocratic mentality wrongly assumes that it's possible know nature 'as it really is,' such that when people physically interact with nature they are dealing with things that are, inter alia, nonsocial. ${ }^{2}$ If, together, the ecocentric and social approaches dissent from conventional geographical understandings of societynature relations, they are also radical in their political commitments. This radicalism has two connected moments: critical diagnosis and normative prognosis. The former entails a deep analysis of conventional understandings of, and interactions with, nature, with a view to eradicating relations of power and domination. The latter entails envisaging a future world in which principles of social and ecological justice organize the society-nature nexus at both the local and global levels. In short, from the ecocentric and social perspectives, taken-for-granted conceptions of nature among geographers and actors in the wider world - policy-makers, businesses, and ordinary people - are seen as part of the problem, not the solution, if societies are to build survivable futures.

Geography has always been a contested enterprise: it has no 'essence.' The discipline, like all others, has constantly changed its spots in response to external pressures and internal debates. Rather than asking what the true 'nature' of geography is, we therefore need to ask: 'who defines geography for what purposes and in whose interests?' This, in effect, is the provocative question that the ecocentric and social approaches ask about the way societynature relations are currently understood and organized. These approaches should therefore be understood as part of the ongoing struggle to define what the geographical project is - and should be - about in the new millennium.

Despite the elective affinity between the ecocentric and social perspectives on nature, this book, as mentioned earlier, focuses exclusively on the latter. There are several good reasons why. Firstly, there are now several excellent introductions to ecocentric thinking. ${ }^{3}$ Secondly, despite the recent explosion of geographical research on 'social nature,' there is currently no one text that describes, explains, and evaluates this work for the benefit of university students (undergraduate and postgraduate) and their teachers. For many geographers, the idea that nature is social still seems odd, even absurd. This is why Social Nature gathers together an international group of experts on the topic to explain both how nature is socialized and why it matters - theoretically, practically, and politically. Finally, there's a more substantive and pointed reason why this book examines the social, rather than ecocentric, approach as an alternative to conventional understandings of nature in geography and beyond. For, from the social perspective, ecocentrism has a crucial and problematic similarity to the technocratic approach it otherwise opposes: that is, it posits a foundational distinction between the social and the natural and 
assumes that the latter is, at some level, fixed andlor universal. Thus, where ecocentrists urge us to 'save,' 'live in harmony with,' or even 'get back to' nature, technocratic geographers propose to 'manage,' 'control,' or 'dominate' nature as if were a domain different to, and separate from, society. Deeply ingrained in Western thought since the Enlightenment, the society-nature dichotomy and the assumption that natural entities are unalterable 'givens' remain 'common sense' - even at a time when developments like gene-splicing have challenged them in dramatic new ways.

In light of this, Social Nature takes two things to be axiomatic. The first is that nature has never been simply 'natural' - whether it's 'wilderness,' resources, 'natural hazards,' or even the human body. Rather, it is intrinsically social, in different ways, at different levels, and with a multitude of serious implications. Second, the all-too-common habit of talking of nature 'in itself,' as a domain which is by definition nonsocial and unchanging, can lead not only to confusion but also the perpetuation of power and inequality in the wider world. From this perspective, then, geographers adopting both a 'people and environment' and an ecocentric approach misleadingly abstract nature from its inextricable social integument.

Without pre-empting too much the essays that follow, I want, in the remainder of this chapter, to outline the different ways that critical geographers currently regard nature as a social artefact. My starting-point is to ask: what is nature? So far, I've used this term as if it were clear-cut and unproblematic. However, as we'll see below, my seemingly simple question demands a complex answer. It's an answer, moreover, that reveals how conventional, but very specific, understandings of the natural have functioned in geography - and indeed society at large - to discipline both people and other species.

\section{The Nature of Nature}

Nature is both a concept and all those physical things to which the concept refers. It's a complex concept, not just because it refers to many different entities - from the weather through animals to human 'nature' and beyond but because it also has multiple meanings. As the philosopher Kate Soper puts in her book What Is Nature?, the concept "is at once ... very familiar and extremely elusive" (1995, p. 1). It is, moreover, a promiscuous concept, in the sense that it is used daily in a multitude of situations by a diverse array of individuals, groups, and organizations. Geographers are only one of several constituencies who routinely invoke the idea of nature in what they do. Others include 'natural scientists', governments (who have the legal power to control and regulate society-nature interactions at home and abroad), businesses (who may, for example, pollute nature or exploit natural resources), the media (who report stories about such things as environmental problems or new develop- 
ments like animal cloning), and the public (think about how often people say things like 'he's naturally intelligent' or 'her illness is genetically inherited'). In this sense, since the founding of geography as an academic discipline, it has both been influenced by, and influenced, wider societal conceptions of nature in Western countries. Despite its complexity, elusiveness, and promiscuity, the idea of nature can arguably be resolved into three chief definitions. Let's take each in turn.

\section{External nature}

The familiar distinction between society and nature indicates a long-standing assumption that nature is external to, and different from, society. Indeed, this assumption seems to be indisputable 'common-sense.' As geographer Neil Smith (1984, p. 2) puts it, "external nature is pristine, God-given, autonomous; it is the raw material from which society is built." Here, then, nature is seen as that which is inherently nonsocial and nonhuman, as captured in the term 'the environment.' This ontological separation of the natural and the social has, since at least the European Enlightenment, been associated with other dualisms organizing our thought, such as rural-urban, country-city, and wildernesscivilization. In geography, it's a separation that has organized teaching and research since Bryce, Mackinder, and others first sought to define the discipline. In the early part of the twentieth century, geographers were especially interested in how the environment determines the shape of human societies and cultures (see, for example, Huntingdon, 1925). By mid-century, they eschewed this simplistic 'environmental determinism' and looked at how an increasingly industrialized West was impacting upon local and international resources (Thomas, 1956). Indeed, the postwar division between human and physical geography led geographers to specialize on one or other 'side' of an increasingly asymmetrical society-nature relation. Today, as noted above, a renewed humans-and-environment form of geography has sought to focus center-stage on how societies worldwide are decisively and destructively altering nature. Yet for all the differences between the environmental determinism of a century ago and contemporary research into 'human impacts on the environment,' both share a common assumption that society and nature are related but ultimately distinct. Interestingly, although ecocentrists are critical of the mainstream 'human-impact' type of geography currently advocated by Stoddart and others, many of them also posit a society-nature separation themselves. For the ecocentric lament that societies are 'destroying' a 'first nature' that needs to be protected in 'biosphere reserves,' 'habitat areas,' and 'wilderness zones,' trades on the distinction between a predatory humanity and a fast-disappearing nonhuman world (see, for example, McKibben, 1989). 


\section{Intrinsic nature}

A second, and related, concept is that of nature as "an inherent and essential quality" of something (Williams, 1980, p. 68). Here nature is seen as (i) fixed and unchanging and (ii) defined by one or other 'essential' quality or attribute. In geography, as in Western society at large, this idea of intrinsic nature has a long history, and has been applied both to 'external nature' and to 'human nature.' Here, then, nature equates with more than simply 'the environment.' Consider, for example, the words of environmental determinist Ellen Semple, writing back in 1911: "The northern peoples of Europe are energetic, provident, serious, thoughtful ... [whereas] the negroes of the equatorial belt degenerate into grave racial faults" (1911, p. 620). Though such racist ideas would not be countenanced today, ideas of nature as a fixed domain definable by one or other key attribute lives on into the present. For instance, pessimists among the 'humans and environment' tradition of geography take the Malthusian line that natural resources are fixed in quantity, such that sooner or later population levels will outstrip them with disastrous consequences (see Lowe and Bowlby, 1996). Similarly, there's still a good deal of research on hazards like floods and earthquakes - that sees them as, essentially, 'natural events' governed by physical laws and processes (see Blaikie et al., 1994, for a critique). Again, ecocentrists too draw upon a repertoire of ideas about nature as an unmalleable, intransigent entity. For instance, for many geographers interested in animals and animal rights, a key part of their argument is that practices like hunting and vivisection are cruel insofar as they inevitably lead to physical pain and even death (for a review of work on 'animal geographies' see Wolch and Emel, 1998).

\section{Universal nature}

Thirdly, and finally, in contradiction to the idea of an external nature, nature is frequently seen as a universal dimension. This has two aspects. One is to see natural characteristics as general rather than particular. For instance, a hydrologist studying how pesticides leak from fields of a certain soil type into rivers might use a general theory of soil water movement. The assumption, here, is that all fields with this soil type - regardless of location - behave in similar ways vis-à-vis water percolation. Secondly, nature is sometimes seen as universal in the sense of encompassing everything there is - humans included insofar as they too, being biological entities, are part of a wider, global, ecological system. This second idea of a universal nature finds its most common expression in socalled 'Gaianist' versions of ecocentrism, where modern, industrialized societies are seen to have disturbed the 'natural order.' In the view of James Lovelock 
(1995) - who has famously popularized this type of ecocentrism (Gaia means 'Earth goddess') - humanity must be seen as part of a holistic, living, integrated earth, one that will exact 'revenge' if humans (especially in the hyperindustrialized West) continue to disrupt the ecosphere.

At once overlapping and different, these three definitions of nature have been - and continue to be - commonplace in both geography and the wider world. Most readers of this book will, I suspect, be very familiar with them - either explicitly or implicitly. Before going on to show why, according to certain critical geographers, "the one thing that is not "natural' is nature ... [it]self" (Soper, 1995: p. 7), it's worth pausing to consider what the three definitions mentioned have in common and what their strengths and weaknesses are.

In terms of commonalities, several things stand out. The first is the belief that nature can be known 'in itself.' In all three definitions, there's a presumption that the 'facts' of nature 'speak for themselves' once geographers have adopted the 'correct' perspective. For mainstream 'human impact' researchers, the 'scientific' methods of physical geography are routinely invoked to yield singular 'truths' about how natural systems operate. In the ecocentric case, things are slightly more complex. In some instances, ecocentrists embrace field science in order to point-up facts about fast-disappearing environments. In others, nonscientific assertions are made about how societies, especially Western societies, are 'disrupting,' 'dominating,' or even 'violating' the inherent 'balance' of nature. In both instances, though, relatively unproblematized truth-claims are made about how nature 'really works.' Secondly, the three definitions of nature outlined above imply that it offers societies a set of possibilities and constraints that are more-or-less unchangeable. Aside from neo-Malthusian 'limits to growth' arguments, often used to justify population control, this idea of an intransigent nature frequently crops up in mainstream resource management, where restrictions on human activities are legitimated in terms of the need to conserve finite (nonrenewable) species or resources. Similarly, although ecocentrists dissent from the instrumental rationality of technocratic approaches to nature, they too often invoke the language of an unmalleable nature. In the 'deep ecology' of Arne Naess (1989), for example, a call is made to do away with all the paraphernalia of modern industrialism in order to 'be at one' (practically and spiritually) with a rapidly-vanishing 'first nature' before it's too late.

Finally, according to the three conventional definitions of nature commonly adhered to in geography and Western societies more generally, it is often invoked to ground value judgments about what is deemed 'good' and 'bad'/ 'normal' and 'abnormal'/'better' or 'worse' - either socially or ecologically. Examples of this abound in both the ecocentric and people-and-environment traditions. For instance, in the former case, the preservation of natural environments is usually taken to be inherently and self-evidently valuable. In the latter 
case, we can cite everything from Semple's egregious argument that 'difficult' environments produce 'inferior races' to the more subtle value claims built into modern physical geography research. Take the case of research into global warming, for instance, where it's sometimes simply assumed that such warming is intrinsically negative because it destroys the atmosphere's 'natural balance'.

The benefits of continued adherence to these deeply-ingrained ways of talking about nature are plain to see. In geography and beyond, whether one's perspective is technocratic or green, it's possible to (i) identify supposedly objective facts about nature and environment, leading to (ii) explanations of how far and in what ways societies are affecting, or being affected by them, in turn generating (iii) an evaluation of society-nature relations on scientific or moral grounds, leading to policy formulations or some shift in society-nature relations at one or more spatial scales. However, there are a number of potentially profound disadvantages with seeing nature as an external, intrinsic and/or universal domain whose 'essential' character can be objectively studied in order to ground value judgments. Three loom large.

Firstly, the 'facts' of nature never simply speak for themselves. In reality, what counts as the truth about nature varies depending on the perspective of the analyst. In other words, however rigorous and scientific one's investigations of the natural might be, there is no easy way to separate objective observations from social biases and political interests. As Raymond Williams (1980, p. 70) famously put it, "What is usually apparent [when reference is made to nature] is that it is selective, according to the speaker's general purpose." Secondly, it follows that statements about nature say as much about who is doing the talking, and what their individual group interests are, as they say about nature tout court. Thirdly, it's often the case that claims about nature - and actions based upon those claims - can serve as instruments of power and domination. Consider, for example, the wildlife conservation movement in the developing world, which has both an ecocentric and technocratic wing. For over a century, in countries like Kenya, indigenous peoples have been forcibly removed from, or denied access to, traditional territories because conservationists have argued that segregated 'wildlife parks' are required for species protection.

If we summarize these three problems, we might say that in each case the social dimensions of nature are ignored, denied, or effaced. But what does it mean to say that nature - which we typically define as nonsocial - is, in fact, social through and through? And what implications - for geographers and all those concerned about society-nature relations more generally - does it have for established ways of thinking about, and acting toward, resources, species, ecologies, and bodies? 


\section{Social Nature}

As noted earlier, it's only in the last few years that geographers' understandings of how nature is socialized have deepened and expanded. As also noted, this outpouring of new work on social nature is associated with critical human geographers - and, as the chapters of this book testify, particularly those of a Marxist, post-Marxist, feminist, antiracist, poststructuralist, anticolonial, and actor-network persuasion. This association with critical thinking can, in fact, be traced back some three decades. For the counterintuitive idea of 'social nature' is not all new to geography - it originated with the first critical geographers like David Harvey (1974), writing in the context of public and governmental concern about global 'overpopulation' and resource scarcity during the mid-1970s. What is new, though, is the volume, diversity, and incisiveness of the recent work on social nature. In short, this work is now at the point where it can be described as distinct and influential approach to understanding nature and environment. Though it's not at all a unified approach - instead, it consists of multiple theoretical, thematic, and political strands - geographical research conducted under the social nature banner does share a set of important characteristics. These pivot on the claim that ideas of nature as either external, intrinsic, or universal are themselves social constructions, specific to Western social formations. To grasp nature's social character, we must therefore not only critique these ideas, but also find a way to see how, in both thought and practice, the natural and the social melt into one another. Simplifying deliberately, critical geographers have insisted that nature is social in three related ways:

\section{Knowing nature}

The first of these I've already touched upon: that is, the claim that knowledge of nature is invariably inflected with the biases of the knower/s. This is the same as saying that there's no singular, objective knowledge of nature, only particular, socially constituted knowledges, in the plural. What's so arresting about this argument is that it can be applied not only to how nature is understood by people, governments, and businesses out there in the wider world, but also to how geographers themselves see (and have seen) nature. It's an argument that's been made by critical geographers in a number of ways. It began life with the work of Marxists like Harvey and Neil Smith, writing in the 1970s and 1980s. Both were critical of the supposedly 'neutral' knowledge of environmental problems produced by the conventional 'human impact' school of geographical research, steeped as it was in the scientific tradition. For instance, in his germinal essay entitled 'Population, Resources and the Ideology 
of science,' Harvey scrutinized the neo-Malthusian arguments of 'scientific' resource analysts writing during the 1970s. Many of these analysts were predicting imminent global resource shortages - of oil, food and timber, for instance - and calling for drastic reductions in population growth, particularly in the developing world (see, for example, Meadows et al., 1972). Put differently, in the name of supposed 'natural limits' to population growth, poor developing nations were being asked to curtail their demographic expansion and conserve resources. In a biting critique, Harvey pointed out that there were, in fact, more than sufficient resources worldwide to feed and provision the entire global population to a high standard of living. The problem, though, is that these resources were controlled by Western nations. Therefore, for Harvey the 'overpopulation' argument was, in fact, a rhetorical cover designed to draw attention away from the real problem: the maldistribution of resources between the West and the rest. To use Smith's (1984, p. 1) terminology, it was an 'ideology of nature' that concealed the truth of social inequity behind the smokescreen of a purportedly scientific, value-free, resource-scarcity analysis.

Writing in the same vein, and at around the same time, a new, radical cohort of human geographers interested in so-called 'natural hazards' - like Kenneth Hewitt (1983) - began to argue that the very notion that earthquakes, tornadoes, and floods were simply natural events was deeply misleading. By showing that hazards impacted disproportionately on the most disadvantaged sections of society, these radicals argued that conventional hazards analysis was guilty of two things: first, diverting attention away from social vulnerability to hazards thus leading, secondly, to superficial hazard response policies. By social vulnerability, Hewitt and others were referring to the fact that it's typically only the poorest in society who lack the means to cope with the destruction caused by hazards. Therefore, the 'technofix' policies so beloved of conventional hazard managers - such as building flood defences or temporarily housing those displaced by a landslide - failed to address the deeper issues of why certain social groups, defined in class terms, are more vulnerable to hazards in the first place.

In these Marxian analyses, geographical knowledges of nature are seen as implicitly and explicitly reflecting the wider class interests of the most powerful groups in Western and non-Western societies. More recently, other critical geographers have argued that knowledges of nature also reflect other interests especially those concerning gender, 'race,' and colonialism. For instance, feminist geographers Cathy Nesmith and Sarah Radcliffe (1997) have criticized the gender subtexts of a good deal of ecocentric thinking. Though such thinking seems politically progressive by virtue of being 'green,' they argue that it's often shot through with highly patriarchal notions of the environment as something to be 'protected' or something that is intrinsically 'nurturing.' By feminizing nature in this specific way, Nesmith and Radcliffe argue, certain ecocentric approaches to nature merely reflect and repeat the stereotypes of 
women that have allowed men to be the dominant gender for most of Western and non-Western history.

Similarly, others have argued that racial stereotypes and racial discrimination - both today and in the past - have been reproduced, in part, by way of attributing to different social groups certain 'inherent' characteristics. Indeed, as a university discipline, geography was implicated historically in what, a century ago, seemed perfectly normal ideas about the 'natural' superiority of Caucasians over non-Western peoples. Illicitly adapting the biologist Darwin's ideas about 'natural selection' among species to the supposed 'fight for survival' among different 'racial' groups, a form of 'social Darwinism' saturated geographical thinking during the early twentieth century. As Richard Peet (1985) has shown, it was thinking that routinely labeled aboriginal and native peoples in colonial territories as 'primitive, 'uncivilized,' and 'backward' - all, of course, 'by nature.' More subtly, and in the contemporary era, Sian Sullivan (2000) argues persuasively that resource managers in many developing countries have perpetuated a set of 'environmental myths' about indigenous land-use habits. These myths - which, for instance, depict herders as 'irrationally' overstocking rangelands - are, Sullivan argues, designed to consolidate the 'expert authority' of the land managers, thus making their advice indispensable for Third World governments.

In their chapters, Jane Moeckli, Kay Anderson, Piers Blaikie, and Derek Gregory all explore these gendered, racialised and colonialised knowledges of nature. Where Marxists like Harvey and Smith talk of ideologies of nature which hide the truth and which serve specific social interests - Moeckli, Anderson and Gregory show that knowledges of nature are more complex than this, in terms of their origins and outcomes. To begin, they prefer to talk of discourses of nature, drawing upon the so-called 'poststructuralist' theories of language proposed by the French intellectuals Derrida and Foucault. Here any claims about nature are seen to draw upon a wide repertoire of other social images and norms - whether of a gender, racial, colonial, national, or other type. Moreover, they argue that it's simply not possible to step outside these complex discourses in order to find out 'what's really going on' in relation to nature. For, as Moeckli, Anderson, and Gregory show, all claims about nature are discursively mediated. Knowledge and language are the tools we use to make sense of a natural world that is both different from us and yet which we are a part of. There is, therefore, no objective, nondiscursive way of comprehending nature 'in the raw.' We have to live with the fact that different individuals and groups use different discourses to make sense of the same nature/s. These discourses do not reveal or hide the truths of nature but, rather, create their own truths. Whose discourse is accepted as being truthful is a question of social struggle and power politics. Furthermore, many nature discourses become so deeply entrenched in both lay and expert ways of thinking that they themselves appear natural. 
Whether one takes the ideology or the discourse line, the critical geographers mentioned above all agree on two things: first, that knowledges of nature (even scientific ones) frequently express social power relations and, second, that these knowledges have material effects, insofar as people may believe and act according to them. 'Deconstructing' these knowledges therefore entails 'denaturalizing' them: that is, showing them to be social products arising in particular contexts and serving specific social or ecological ends that ought to be questioned.

\section{Engaging nature}

Though knowledges of nature are social through and through, the social dimensions of nature are not reducible to knowledge alone. For the societynature nexus, of course, has an insistently practical side to it: to wit, societies, past and present, always physically interact with nature. The form and consequences of this physical interaction is, as noted earlier, a key concern of both the technocratic and ecocentric approaches to nature in geography. However, as I also observed earlier, both approaches tend to see nature, in the physical sense, as nonsocial. It is this notion of a nonsocial nature that underpins the familiar geographical vocabulary of societies 'impacting on,' 'interfacing with,' or 'destroying' environments. Against this, many critical geographers insist that it's impossible to physically disentangle the social and the natural. In reality, all there is - to borrow Erik Swyngedouw's (1999, p. 443) apt neologism - is "socionature."

What does this mean? It is not at all a denial of the material reality of those things we routinely call natural - be they trees, rivers, animals, or anything else. Rather, it's an insistence that the physical opportunities and constraints nature presents societies with can only be defined relative to specific sets of economic, cultural, and technical relations and capacities. In other words, the same 'chunk' of nature - say the Amazon rainforest - will have different physical attributes and implications for societies, depending on how those societies use it. In this sense, the physical characteristics of nature are contingent upon social practices: they are not fixed. Critical geographers have, in recent years, made this important argument in four main topic areas.

The first of these is the above-mentioned field of hazards research, where it's now argued that hazards can only be defined relative to the vulnerability of different groups in society (see Blaikie et al.'s 1994 landmark book At Risk). This argument is explored in more depth in Mark Pelling's chapter in this volume. Second, and relatedly, several human geographers have sought to question conventional understandings of a particularly distressing phenomenon that, sadly, remains a reality for millions today: famine. For instance, Lakshama Yapa (1996), drawing upon the seminal work of radical economist Amartya 
Sen, has argued that natural events like droughts merely trigger famines but do not cause them. Though this claim seems odd at first sight, Yapa's point is that famines often happen in situations of food surplus! Taking examples from the developing world, he shows that some people starve during droughts not because of absolute food shortages, but because they lack the economic wealth ('entitlements') to purchase much-needed food within their own country or community. Starvation is thus, for Yapa, a class-specific phenomenon.

Thirdly, this feeds into critical geographic work on 'Third World political ecology.' This work examines a plethora of society-nature relationships in developing countries, focusing particularly on the poor. One of the fundamental insights of this work is that the way poor communities use (and abuse) local resources depends as much upon extralocal economic, political, and social forces as it does upon the nature of the resources themselves. For instance, in Silent Violence - one of the early, key texts in political ecology - Michael Watts (1983) looked at Hausa agriculture in northern Nigeria. For centuries, the Hausa had successfully adapted their agronomy to the semiarid environment in which they lived. However, after the onset of British colonialism in the late nineteenth century, they suffered a series of major famines. The reason, Watts showed, was because the British had undermined traditional agriculture and replaced it with the commercial production of cotton and groundnuts for export. Thus, now dependent on two main cash crops, the Hausa lost their self-sufficiency and became subject to the vagaries of foreign markets. During times when exports were low, Watts revealed how the Hausa lacked the economic means to purchase adequate foodstuffs and so became vulnerable to drought. More recently, political ecologists have complemented this focus on the physical aspects of society-nature relations with a focus on knowledges of nature and their power-geometries. Raymond Bryant's chapter critically evaluates these two generations of political ecology perspectives.

Finally, and most recently, critical geographers have highlighted the phenomenon of 'environmental in/justice' in the developed world. In Dumping in Dixie, radical academic Robert Bullard (1990) showed some years ago that black and working-class Americans suffered a disproportionate exposure to toxic waste and pollution. Since then, many human geographers in the US, UK, and other Western countries have been concerned to show that this exposure is not 'accidental.' Rather, they have argued, it is due to the deliberate siting of noxious facilities - for instance, waste incinerators - in or near communities with the lowest capacity to contest them in the political or legal system (see the special issue of Antipode (1996) on 'Waste, Race and Class'). 


\section{Remaking nature}

It's one thing to say that societies physically engage with nature in ways that blur the boundaries between the two. But it's another to argue that societies physically reconstitute nature, both intentionally and unintentionally. Yet it's an argument many critical geographers have been prepared to make. Here, the natural - in a very material way - is seen to have become internal to social processes, particularly in advanced Western societies. Ideas of nature as external, intrinsic, or universal are, it's argued, therefore radically out of step with the reality of a nature that is social 'all the way down.' This argument has been made from three perspectives. First, from the mid-1980s, the already mentioned Marxist geographer Neil Smith argued that modern, industrial capitalism was, quite literally 'producing nature' in the narrow interests of profitability. Genetically modified organisms, manufactured by transnational agrofood companies, are only the latest example of what Smith was referring to. Today, a cohort of Marxist and neo-Marxist geographers, with interests in modern agriculture in particular, have taken Smith's ideas forward. In my chapter later in this book, I explain the idea of the production of nature at length.

Smith's account highlighted how science and technology were deeply implicated in capitalist development. But ultimately neither is reducible to the class interests of capitalist businesses alone. Hence, in the last few years, the roles of science and technology in remaking nature have become a focus of critical geographic attention in their own right. Drawing upon so-called 'sociology of scientific knowledge,' some have argued that scientists intentionally alter nature for very specific purposes that reflect more than simply 'scientific' interests. As science historian Ian Hacking (1983) said, science does not merely study the world but intervenes in it, physically and practically Scientists, both in the laboratory and the field, increasingly create what geographer David Demeritt (1998) calls "artefactual natures," ones that are purposefully engineered - even down to the genetic level. The question then arises: what types of artefactual natures exist today, for whose benefit and with what socioecological consequences?

This question brings me the final main perspective on how societies materially manufacture nature. It's a perspective first developed by German sociologist Ulrich Beck (1992) in his book Risk Society, and focuses on the powers of advanced industrial technologies. Beck's central point is that Western societies are now physically reconstituting nature in ways that, alarmingly, escape their control. Phenomena like acid deposition and the presence of pesticide residues in the food chain are, he argues, 'manufactured risks,' which are the unintentional and uncontrollable byproduct of mass industrialism. In geography, this argument has stimulated a good deal of debate (see, for example, 
Eden 1998), and conjures up the apocalyptical idea that we're witnessing 'the end of nature' in the twenty-first century.

\section{The Social Construction of Nature?}

In the several ways outlined above, nature has come to be seen as never simply, or not even, natural. Understandably, the idea of 'social nature' has not been well received in all parts geography or, indeed, in other disciplines where it's been expounded - like environmental sociology. Notwithstanding the differences between the technocratic and ecocentric approaches to nature, advocates of both have expressed common concerns about the social-nature perspective. Chief among these is the accusation that this perspective licences the outlandish idea that nature is nothing more than a social construction. This idea is clearest in those arguments concerning the physical remaking of nature, where nature, it seems, is depicted as mere putty in the hands of modern science, technology, and business. But it also appears in arguments concerning knowledges of nature. Consider, for instance, the words of geographer William Cronon (1996, p. 69), in his deconstruction of the idea of 'wilderness': "[wilderness] is a profoundly human construction ..., it hides its unnaturalness behind a mask that is all the more beguiling because it seems so natural."

Understandably, technocratic and ecocentric geographers worry that these kinds of arguments are intellectually misguided, and practically and politically debilitating. They are misguided because they apparently deny the physical reality and autonomy of nature from societies. In the case of the material construction of nature - à la Smith, Demeritt, Beck, and others - it appears as if the physical attributes of nature can be comprehensively manipulated by advanced Western societies. But this 'hyperconstructionist' view, its critics argue, ignores two facts: first, that some aspects of nature - like geology - are simply not amenable to physical alteration; and second, that even those that are - like GM seeds - are not completely subject to social control because their operation is not 100 percent predictable. Likewise, several technocratic and ecocentric geographers have been skeptical of the idea that nature is constructed ideologically/discursively. For if nature is only an idea - if it cannot be 'objectively' known - then, these geographers claim, we're led to the absurd conclusion that nature is whatever we want it to be.

If these criticisms are accurate, then it's clear why social nature arguments might seem practically and politically debilitating to some. They seem practically debilitating because they evidently prevent us from acting in and on nature in appropriate ways. For instance, if 'global warming' is simply a fabrication - a myth cooked-up by atmospheric scientists keen to secure large research grants for the kind of work they do - then we are led to conclude that polluting the atmosphere is okay, since we can never know the 'real' climatic 
effects of greenhouse gases. On the political front, the idea that nature is socially constructed seems to deny that nature can ground any value judgments about appropriate social or ecological behavior. How, for example, can ecocentrists claim that killing whales or destroying the Amazon is wrong, if we can no longer "appeal to nature as a stable external source of nonhuman values" (Cronon, 1996: p. 26)?

Though these criticisms are valid, they can only be made to stick if some or all of the geographical work on social nature is truly guilty of a hyperconstructionist view. However, as the contributors to this book show, this work generally eschews such an extreme stance. For however social nature is, it would be difficult to deny the reality of those myriad things societies define as 'natural.' The point, as David Demeritt shows in his chapter in this volume, is simply that there is never any way to access, evaluate, and affect nature that does not involve socially specific knowledges and practices (see also Proctor, 1998). We must live with this inability to know nature 'as it really is,' while still remaining commited to the idea that some knowledges of, and practices on, nature are better or worse than others.

This point can be taken even further. The questionable idea of nature being nothing more than a social construction not only exaggerates the power of societies but also arguably trades on the society-nature dualism that I criticized earlier in this chapter. For it implies that nature is a tabula rasa on which societies can write at will. Against this, critical geographers like Sarah Whatmore have drawn upon a new 'actor-network theory' to show that societies do not construct nature as they please. Rather, myriad 'social' and 'natural' entities are indissolubly conjoined as 'hybrids' in millions of actor-networks organized at multiple geographical scales. In this view, societies are 'in' nature (and vice versa) such that it becomes hard to understand who or what is doing the constructing. In the chapter written with Tom MacMillan, we explore and evaluate this exciting new perspective.

\section{Theory, Practice, and Politics}

Clearly, the new geographical ideas about social nature are as diverse as they are important. The chapters that comprise this book aim to give readers a comprehensive, though not exhaustive, critical introduction to these ideas. By way of a conclusion to this introductory essay, I want to signpost three key themes that run throughout the pages of Social Nature.

The first of these relates to theory. Theory is a complex and ambiguous word, but for many geographers - and particularly students - it often has a pejorative association with thinking that is abstract, conceptual, or just plain woolly. Against this, the chapters of Social Nature all show why theory is absolutely vital if we're to make proper sense of society-nature relations, past, 
present, and future. In this book, the term 'theory' refers to formal intellectual frameworks for explaining and evaluating myriad different society-nature imbrications. More specifically, the theories discussed in each chapter are critical, that is, ones concerned with questions of socionatural in/justice. They seek to question conventional understandings and practices regarding nature technocratic, ecocentric, or otherwise - and they try, implicitly or explicitly, to envisage more progressive society-nature articulations.

Theory, however, can become irrelevant if it lacks direct connections to real world events. This is why, secondly, the chapters of Social Nature all seek to show how theory can make sense of the society-nature nexus in practice. This has two aspects. First, all the contributors show how many actors in society - from geographers themselves to the public to policy-makers - routinely misunderstand or misrepresent society-nature relations. Second, they show how the theories and concepts they present can illuminate what is so often denied: that is, nature's implication in social knowledge, practice, and power. In these two ways, readers will hopefully appreciate not only the 'power' of critical theory but gain empirical insights into nature's social dimensions.

Finally, all the chapters of this book are preoccupied with the politics of nature. For if nature is nothing if it's not social, it's also unavoidably political. Like theory, politics is a complex term. In Social Nature, the contributors unpack this term into three related meanings. The first of these is politics as values. Knowledge of, and action in/on, nature is unavoidably value-laden. It speaks volumes not only about who is doing the knowing and acting, but what kind of a world they are trying to forge. This is often subtle - as in the hidden values written into scientific knowledges of nature - but by no means always. Social Nature encourages readers to reflect carefully and critically upon the social value commitments involved in all society-nature relations. Second, we can understand politics as moral or ethical statements about nature. Morality and ethics are those principles societies use to determine what is 'right' and 'proper' thought or behavior. For instance, ecocentrists question the humancentered morals used to evaluate current society-nature relations worldwide and call for a less anthropocentric and more 'green' ethical code. In his chapter, James Proctor considers whether or not we can have an environmental ethics that 'defends nature' if all ethical judgments are inherently social and constructed. Finally, we can think of politics in the familiar sense of formal governmental policies and decision-making. Governments and bureaucracies - at a variety of scales - are responsible for both regulating and shaping societynature relations. Typically, though not always, they deal with nature in technocratic ways. Several chapters in this book question the nonsocial view of nature written into state politics and policy, as well as the ecocentric criticisms of these politics and policies. They therefore insist that states, bureaucracies, and their ecocentric critics must all acknowledge nature's sociality from the 
very start, if adequate policy measures are to be developed over everything from deforestation to the patenting of life forms.

To sum up, in an era when nature is less natural than at any time in human history - an era when even the human body is becoming subject to social reengineering - it seems to me that geographers must become participants in, not spectators of, the momentous socionatural changes of our time. Social Nature is designed to give readers the tools to think critically about the dominant ideas and practices that circumscribe all manner of society-nature relations worldwide. The question it opens up for discussion is a crucial and profound one: what kinds of nature - or more properly natures, in the plural do we want for what kind of future?

\section{Notes}

1 There are now many books in this 'people and environment' tradition of geography that are aimed at students. Two recent examples are Middleton's (1995) The Global Casino and Pickering and Owen's (1997) An Introduction to Global Environmental Issues.

2 The social and ecocentric appoaches to understanding society-nature relations do overlap in several substantive areas, in part because both approaches are internally diverse. However, for didactic purposes, I'm deliberately emphasizing the differences between them here.

3 See, for example, David Pepper's (1996) Modern Environmentalism. Though several texts like this now exist, ecocentrism is not, in fact, widely advocated by critical geographers. This is odd, since in the wider world it enjoys support among a significant minority of people, finding expression in the ideas and practices of many nongovernmental organizations and so-called 'new social movements' - like Greenpeace, Earth First!, and genetiXsnowball.

\section{Further Reading}

For more on the concept of nature see Castree (2000), Gold (1984), or Smith (1998, ch. 1). Phillips and Mighall (2000, ch. 1) offer a useful overview of different approaches to society and nature. O'Riordan (1996) gives a good introduction to technocratic and ecocentric approaches. 


\section{References}

Beck, U. (1992). Risk Society. London: Sage.

Blaikie, P., Cannon, T., Davis, I., and Wisner, B. (1994). At Risk. London: Routledge. Bryce, J. (1886). The Relations of History and Geography. Contemporary Review 49: 426-43.

Bullard, R. (1990). Dumping in Dixie. Boulder: Westview Press.

Castree, N. (2000). Nature. In R. Johnston et al. (eds.) The Dictionary of Human Geography, fourth edn. Oxford: Blackwell, 537-40.

Cooke, R. (1992). Common Ground, Shared Inheritance. Transactions of the Institute of British Geographers 17: 131-51.

Cronon, W. (ed.) (1996). Uncommon Ground. New York: W. W. Norton.

Demeritt, D. (1998). Science, Social Constructivism and Nature. In B. Braun and N. Castree (eds.) Remaking Reality. London: Routledge, 173-92.

Eden, S. (1998). Knowledge, Uncertainty and the Environment. Progress in Human Geography 22: 425-32.

Gold, M. (1984). A History of Nature. In D. Massey and J. Allen (eds.) Geography Matters! Cambridge: Cambridge University Press, 12-33.

Hacking, I. (1983). Representing and Intervening. Cambridge: Cambridge University Press.

Harvey, D. (1974). Population, Resources and the Ideology of Science. Economic Geography 50: 256-77.

Hewitt, K. (ed.) (1983). Interpretations of Calamity. London: Allen and Unwin.

Huntington, E. (1925). The Character of Races. New York: Charles Scribner.

Lovelock, J. (1995). The Ages of Gaia. Oxford: Oxford University Press.

Lowe, M. and Bowlby, S. (1996). Population and Environment. In A. Mannion and S. Bowlby (eds.) Environmental Issues in the 1990s. Chichestrer: Wiley, 117-30.

McKibben, R. (1989). The End of Nature. New York: Vintage.

Meadows, D. et al. (1972). The Limits to Growth. New York: Universe Books.

Middleton, N. (1995). The Global Casino. London: Arnold.

Naess, A. (1989). Ecology, Community and Lifestyle. Cambridge: Cambridge University Press.

Nesmith, C. and Radcliffe, S. (1997). Remapping Mother Earth. In T. Barnes and D. Gregory (eds.), Reading Human Geography. London: Arnold, 195-210.

O'Riordan, T. (1996). Environmentalism on the Move. In I. Douglas et al. (eds.), The Companion Encyclopedia of Geography. London: Routledge, 449-78.

Peet, R. (1985). The Social Origins of Environmental Determinism. Annals of the Association of American Geographers 75: 309-33.

Pepper, D. (1996). Modern Environmentalism. London: Routledge.

Phillips, M. and Mighall, T. (2000). Society and Nature through Exploitation Harlow: Prentice Hall.

Pickering, K. and Owen, L. (1997). An Introduction to Global Environmental Issues. London: Routledge.

Proctor, J. (1998). The Social Construction of Nature. Annals of the Association of American Geographers 88: 352-76.

Redclift, M. (1996). Wasted: Counting the Costs of Global Consumption. London: Earthscan. 
Semple, E. (1911). The Influences of Geographic Environment. New York: Henry Holt. Smith, M. (1998). Ecologism. Milton Keynes: Open University Press.

Smith, N. (1984). Uneven Development. Oxford: Blackwell.

Soper, K. (1995). What Is Nature? Oxford: Blackwell.

Stoddart, D. (1987). To Claim the High Ground. Transactions of the Institute of British Geographers 12: 327-36.

Sullivan, S. (2000). Getting the Science Right, or Introducing Science in the First Place? In P. Stott and S. Sullivan (eds.) Political Ecology. London: Arnold, 15-44.

Swyngedouw, E. (1999). Modernity and Hybridity. Annals of the Association of American Geographers 89: 443-65.

Thomas, R. (ed.) (1956). Man's Role in Changing the Face of the Earth. Chicago: Chicago University Press.

Watts, M. (1983). Silent Violence. Berkeley: University of California Press.

Williams, R. (1980). Problems of Materialism and Culture. London: Verso.

Wolch, J. and Emel, J. (eds.) (1998). Animal Geographies. London: Verso.

Yapa, L. (1996). Improved Seeds and Constructed Scarcity. In R. Peet and M. Watts (eds.), Liberation Ecologies. London: Routledge, 69-85. 